\title{
CXCL8 derived from tumor-associated macrophages and esophageal squamous cell carcinomas contributes to tumor progression by promoting migration and invasion of cancer cells
}

\author{
Masayoshi Hosono ${ }^{1,2}$, Yu-Ichiro Koma ${ }^{1}$, Nobuhisa Takase ${ }^{1,2}$, Naoki Urakawa ${ }^{1,2}$, \\ Nobuhide Higashino ${ }^{1,2}$, Kazuki Suemune ${ }^{1}$, Himiko Kodaira ${ }^{1}$, Mari Nishio ${ }^{1}$, Manabu \\ Shigeoka $^{1}$, Yoshihiro Kakeji ${ }^{2}$ and Hiroshi Yokozaki ${ }^{1}$ \\ ${ }^{1}$ Division of Pathology, Department of Pathology, Kobe University Graduate School of Medicine, Chuo-ku, Kobe 650-0017, \\ Japan \\ ${ }^{2}$ Division of Gastro-intestinal Surgery, Department of Surgery, Kobe University Graduate School of Medicine, Chuo-ku, Kobe \\ 650-0017, Japan \\ Correspondence to: Hiroshi Yokozaki, email: hyoko@med.kobe-u.ac.jp \\ Keywords: CXCL8; esophageal squamous cell carcinoma; tumor-associated macrophage; tumor progression; tumor \\ microenvironment \\ Received: July 19, $2017 \quad$ Accepted: October 28, $2017 \quad$ Published: November 20, 2017 \\ Copyright: Hosono et al. This is an open-access article distributed under the terms of the Creative Commons Attribution License \\ 3.0 (CC BY 3.0), which permits unrestricted use, distribution, and reproduction in any medium, provided the original author and \\ source are credited.
}

\section{ABSTRACT}

Tumor-associated macrophages (TAMs) are involved in tumor progression and poor prognosis in several malignancies. We previously demonstrated the interaction between high numbers of infiltrating TAMs and poor prognosis in esophageal squamous cell carcinomas (ESCCs). To investigate the significance of TAMs in ESCC, we conducted a CDNA microarray analysis of peripheral blood monocytes (PBMo)derived macrophages and PBMo-derived macrophages stimulated with conditioned media of TE-series ESCC cell lines (TAM-like PBMo-derived macrophages). $C-X-C$ motif chemokine ligand 8 (CXCL8) was up-regulated in the TAM-like PBMo-derived macrophages. Here we confirmed a high expression level of CXCL8 in TAM-like PBModerived macrophages and the expression of CXCR1/2, known as CXCL8 receptors, in TE-series ESCC cell lines. Recombinant human CXCL8 induced the ESCC cell lines' migration and invasion by the phosphorylation of Akt and Erk1/2. In indirect cocultures, not only signal pathway inhibitors but also neutralizing antibodies against CXCL8, CXCR1 and CXCR2 suppressed these phenotypes induced by TAM-like PBModerived macrophages. Immunohistochemical analysis of 70 resected ESCC samples showed that high expression levels of CXCL8 in ESCC tissues were significantly associated with lymph node metastasis and poor prognosis. These results suggest that CXCL8 up-regulated in the microenvironment may contribute to ESCC progression by promoting cancer cells' migration and invasion.

\section{INTRODUCTION}

The tumor microenvironment has important roles in tumor progression [1]. Cancer stroma consists of non-cancer cells such as fibroblasts, macrophages, neutrophils, natural killer cells, dendritic cells, vascular endothelial cells and extracellular matrix.
Macrophages are the main cellular component of the tumor microenvironment. From an oncologic viewpoint, macrophages have two different functions; i.e., as tumor suppressive (M1) or tumor supportive (M2) cells. M2 macrophages, which express high interleukin (IL)-10 and low IL-12, play roles in the wound healing process, allergies, and pro-tumoral activity. They display the 
specific receptors known as hemoglobin scavenger receptor (CD163), macrophage scavenger receptor I (CD204), and mannose receptor (CD206) [2, 3]. Tumorassociated macrophages (TAMs) polarize into the M2-like phenotype and are involved in tumor growth, invasion, angiogenesis and metastasis formation [4]. In several cancers, a high level of TAMs infiltrating into the tumor site is associated with poor prognosis [5-8].

In 2012, esophageal cancer was the eighth most common cancer and sixth leading cause of cancerassociated mortality worldwide, at an estimated 455,800 esophageal cancer cases and 400,200 cancer deaths [9]. In the Western world, esophageal adenocarcinoma is a common histological subtype of esophageal cancer. In contrast, in Asian countries including Japan, squamous cell carcinoma accounts for $>90 \%$ of esophageal cancer cases, but the number of esophageal adenocarcinomas is increasing in Asian countries [9, 10]. Not only alcohol and smoking but also genetic factors such as aldehyde dehydrogenase 2 (ALDH2) and alcohol dehydrogenase $1 B(A D H 1 B)$ have been identified as risks for esophageal squamous cell carcinoma (ESCC) $[11,12]$. As ESCCs have a tendency to metastasize to lymph nodes in the early stage, ESCC patients tend to show poor prognoses.

Using immunohistochemistry, we previously demonstrated that a high number of CD204-positive TAMs infiltrating the tumor site are significantly associated with the histological grade, depth of tumor invasion, vessel invasion, lymph node metastasis, clinical stage, and poor prognosis in ESCC patients [13]. To explore the interaction between ESCCs and TAMs, we compared gene expression profiles between peripheral blood monocyte (PBMo)derived macrophages and PBMo-derived macrophages stimulated with conditioned media of TE-series ESCC cell lines (TECM) (TAM-like PBMo-derived macrophages) by performing a cDNA microarray analysis [14]. Among up-regulated molecules, we previously demonstrated that GDF15 was associated with poor prognosis, promoting the migration of ESCC cells [14] and that NCAM accelerated the migration and survival of TAM-like PBMo-derived macrophages [15].

In the present study, we focused on one of the upregulated genes in TAM-like PBMo-derived macrophages, $C-X-C$ motif chemokine ligand 8 (CXCL8). CXCL8 is also known as interleukin-8 (IL-8), and it activates receptors CXCR1 and CXCR2. CXCL8 was reported to be associated with tumor progression in breast cancer [16], colorectal cancer [17], non-small cell lung cancer [18], gastric cancer [19] and melanoma [20]. However, the interaction between CXCL8 derived from TAMs and ESCCs has not been established. Our present findings demonstrate the critical role and biological effect of CXCL8 derived from TAMs in the ESCC microenvironment.

\section{RESULTS}

\section{Expression of CXCL8 in PBMo-derived macrophages and TAM-like PBMo-derived macrophages}

We first confirmed the expression level of CXCL8 in TAM-like PBMo-derived macrophages. The CXCL8 mRNA expression was significantly up-regulated by TECM (TE-8, TE-9 and TE-15) compared to PBModerived macrophages and PBMo-derived macrophages stimulated by Het-1A CM (Figure 1A). The expression level of $C X C L 8$ was also significantly up-regulated by recombinant human (rh) IL- 4 compared to PBModerived macrophages (Supplementary Figure 1). Immunofluorescence demonstrated that CXCL8 was strongly expressed in the cytoplasm of TAM-like PBModerived macrophages (TE-8, TE-9 and TE-15) compared to the PBMo-derived macrophages and PBMo-derived macrophages stimulated by Het-1A CM (Figure 1B). The enzyme-linked immunosorbent assay showed that the concentration of secreted CXCL8 was significantly higher in the PBMo-derived macrophages stimulated with TE-8 CM, TE-9 CM and TE-15 CM (19664.8 $\pm 64.3,17108.3$ \pm 601.8 , and $15560.9 \pm 179.4 \mathrm{pg} / \mathrm{ml}$, respectively) than in the PBMo-derived macrophages $(2423.8 \pm 78.2 \mathrm{pg} / \mathrm{ml})$ (Figure 1C). The concentration of CXCL8 secreted from TE-15 (10025.8 $\pm 711.6 \mathrm{pg} / \mathrm{ml})$ was significantly higher than that in the PBMo-derived macrophages (Figure 1C). The concentration of CXCL8 derived from TE- 8 and TE-9 $(168.1 \pm 13.0$ and $596.4 \pm 23.3 \mathrm{pg} / \mathrm{ml})$ was lower than that in the PBMo-derived macrophages (Figure 1C).

\section{CXCL8 activated Akt and Erk1/2 via the CXCR1/2 of ESCC cells}

We confirmed the expressions of CXCR1 and CXCR2 (which are CXCL8 receptors) on the ESCC cell lines (TE-8, TE-9 and TE-15) by RT-PCR (Figure 2A) and western blotting (Figure 2B), respectively. To investigate the effect of CXCL8 on the post-receptor signaling of ESCC cells, we applied rhCXCL8 at $10 \mathrm{ng} / \mathrm{ml}$ to TE-8, TE-9 and TE-15 under serum-free conditions. We observed the phosphorylation of Akt (Ser473/Thr308) (the PI3K-Akt signal pathway) and Erk1/2 (the MEK-Erk1/2 signal pathway) after $10 \mathrm{~min}$ (Figure 2C).

\section{CXCL8 induced the migration and invasion of TE-8 and TE-9 cells}

First, we demonstrated rhCXCL8 did not promote the migration of TE-15 (expressing high level of CXCL8) (Supplementary Figure 2A) and neutralizing antibody against CXCL8 tended to suppress its migration (Supplementary Figure 2B). As we subsequently assessed 
the effect of CXCL8 derived from TAMs on the phenotype of the ESCC cell lines, we used TE-8 and TE-9 cells expressing low levels of CXCL8. We confirmed that rhCXCL8 had no effect on the proliferation or survival of TE cells (Supplementary Figure 3). We found that rhCXCL8 significantly accelerated the migration and invasion of TE-8 and TE-9 cells by performing a transwell migration assay and transwell invasion assay

A

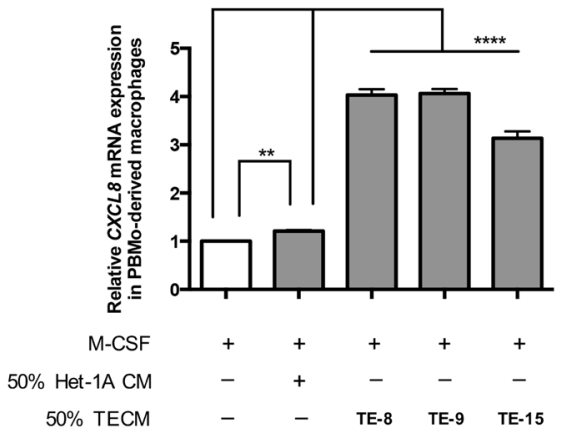

B

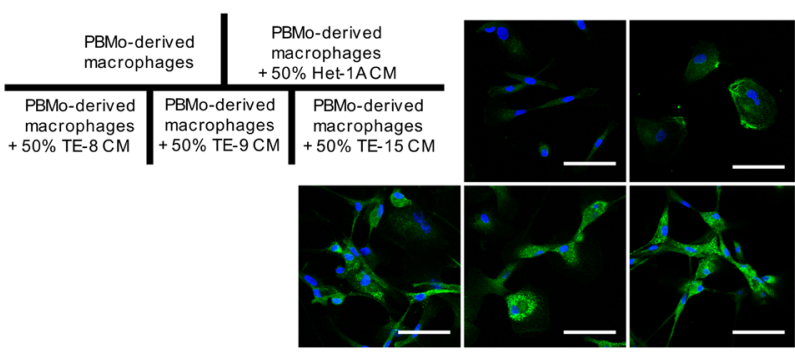

CXCL8 / DAPI

C

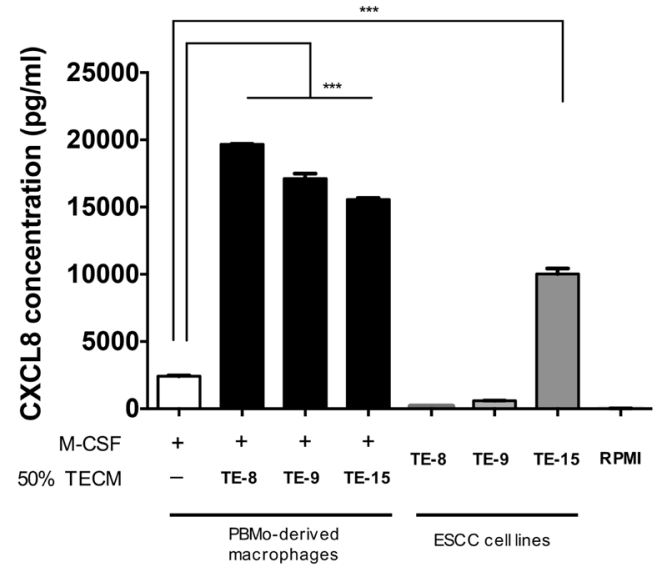

Figure 1: Induction of CXCL8 in PBMo-derived macrophages stimulated with TECM. (A) The mRNA level of $C X C L 8$ in PBMo-derived macrophages stimulated with 50\% TECM or 50\% Het-1A CM was determined by quantitative RT-PCR. The data were normalized to GAPDH as an internal control. Data are mean \pm SEM in triplicate. ${ }^{* *} p<0.01,{ }^{* * * *} p<0.0001$. (B) Expression of CXCL8 in PBMo-derived macrophages stimulated with TECM or Het-1A CM was confirmed by immunofluorescence using anti-CXCL8 antibody (green). Nuclei were stained with DAPI (blue). Magnification $\times 400$. Scale bar, $50 \mu \mathrm{m}$. (C) Concentration of CXCL8 protein in conditioned medium of PBMo-derived macrophages stimulated with TECMs and ESCC cell lines. Protein levels were measured by ELISA. RPMI, negative control RPMI-1640 medium with serum. Data are mean \pm SEM in triplicate. ${ }^{* * *} p<0.001$. 
A

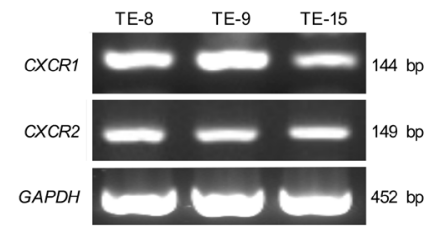

C

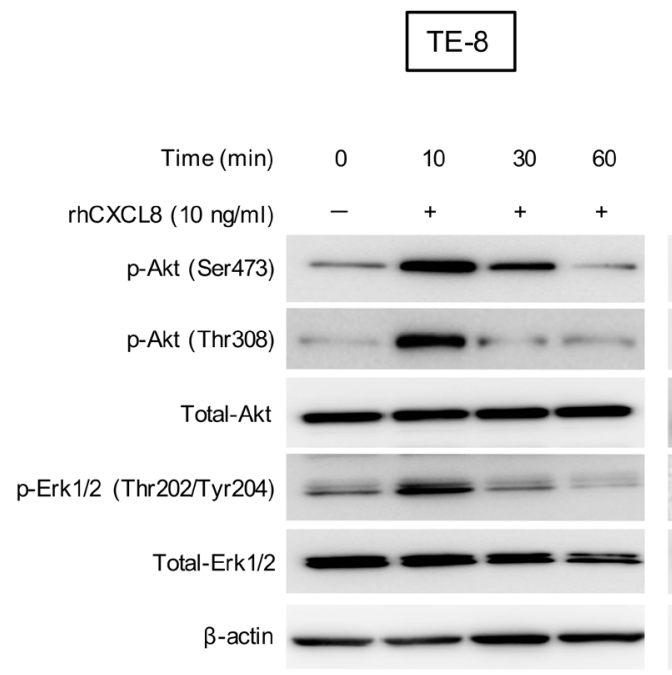

p-Akt (Ser473) / ß-actin

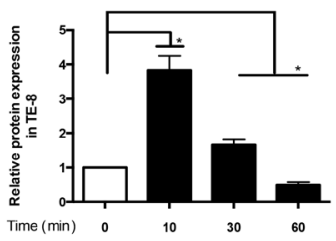

p-Akt (Thr308) / B-actin
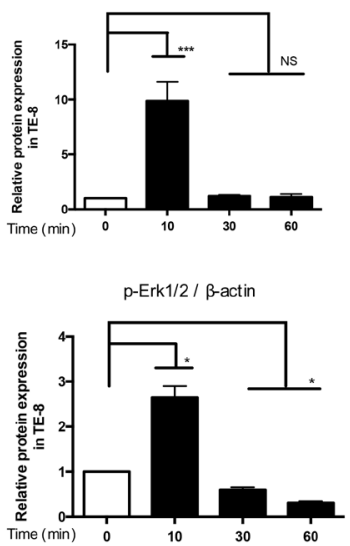

B

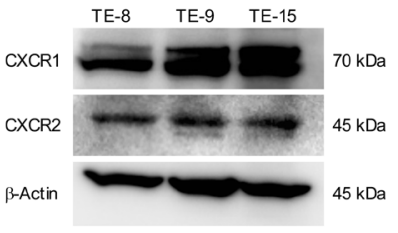

$60 \mathrm{kDa}$
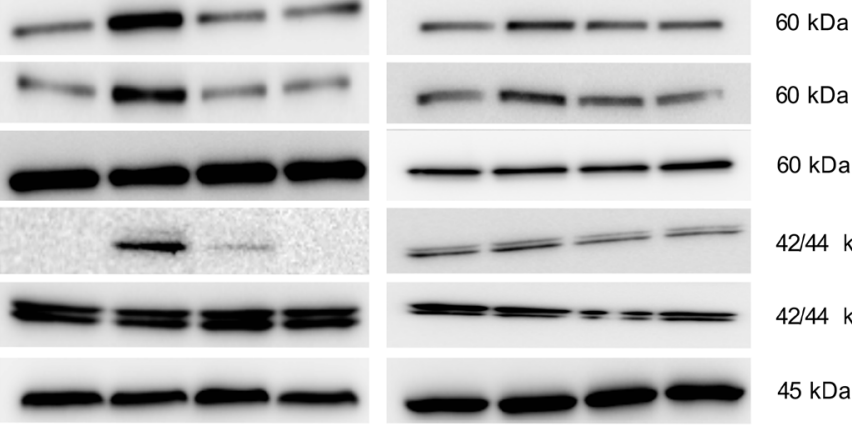

$60 \mathrm{kDa}$

$42 / 44 \mathrm{kDa}$

$42 / 44 \mathrm{kDa}$

$45 \mathrm{kDa}$
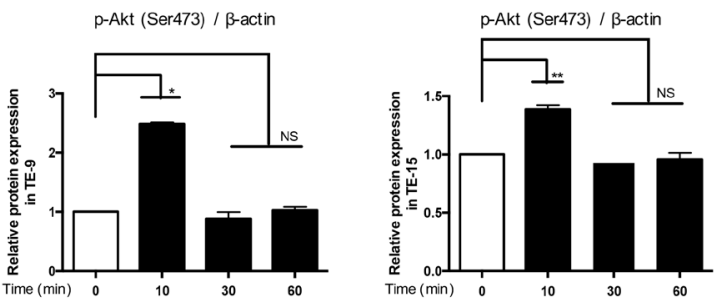

p-Akt (Thr308) / ß-actin
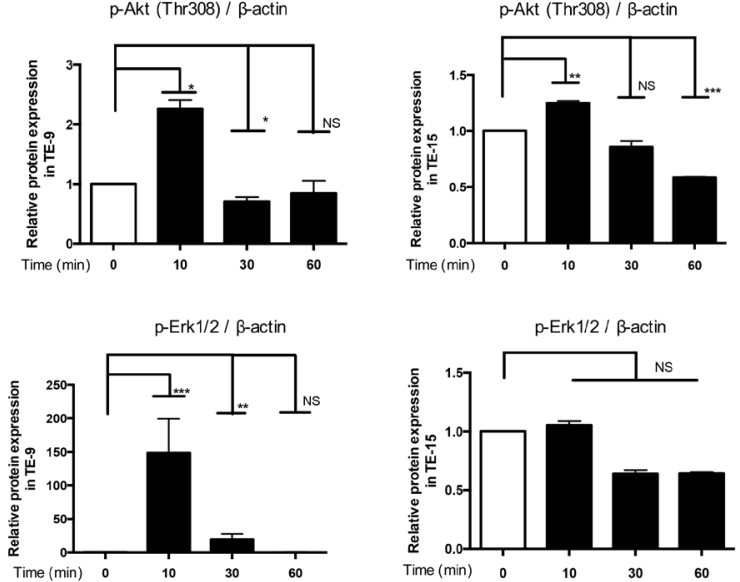

Figure 2: Akt and Erk1/2 were phosphorylated by CXCL8 through CXCR1 and CXCR2 in the ESCC cell lines. (A) The mRNA levels of $C X C R 1$ and $C X C R 2$ in the ESCC cell lines were quantified by RT-PCR. (B) The protein level of CXCR1 and CXCR2 in the ESCC cell lines was confirmed by western blotting. Anti-CXCR1, CXCR2 and $\beta$-actin antibodies were used. (C) TE-8, TE-9 and TE15 cells in serum-free conditions were treated with $10 \mathrm{ng} / \mathrm{ml}$ rhCXCL8 for $0,10,30$ and $60 \mathrm{~min}$. Western blotting was conducted with total protein extracted from ESCC cell lines using specific antibodies against Akt, p-Akt (Ser473), p-Akt (Thr308), Erk1/2, p-Erk1/2 (Thr202/ Tyr204) and $\beta$-actin. Densitometric analysis of bands was performed with ImageJ (National Institutes of Health, Maryland, USA). The results are mean \pm SEM. ${ }^{*} p<0.05,{ }^{* *} p<0.01,{ }^{* * * *} p<0.001$. 
(Figure 3A (i)-(ii), Supplementary Figure 4A (i)-(ii)). LY294002, a PI3K inhibitor, and PD98059, a MEK1/2 inhibitor, suppressed the migration and invasion of TE-8 and TE-9 cells induced by rhCXCL8 (Figure 3B (i)-(ii), Supplementary Figure 4B (i)-(ii)).

We next suppressed the $C X C R 1$ and $C X C R 2$ of TE-8 and TE-9 cells by RNA interference. The silencing levels of $C X C R 1$ and $C X C R 2$ of TE- 8 cells were confirmed by western blotting (Figure 3C). CXCL8 did not stimulate the migration and invasion of CXCR1- or CXCR2-silenced TE-8 and TE-9 cells (Figure 3D (i)-(ii), Supplementary Figure 4C (i)-(ii)). The neutralizing antibodies against CXCR1 or CXCR2 reduced the migration and invasion of TE-8 and TE-9 cells induced by rhCXCL8 (Figure 3E (i)-(ii), Supplementary Figure 4D (i)-(ii)).

\section{Inhibitors against PI3K and MEK1/2 and neutralizing antibodies against CXCL8, CXCR1, and $\mathrm{CXCR2}$ suppressed the migration and invasion of TE-8 and TE-9 cells induced by TAM-like PBMo-derived macrophages}

We investigated whether TAM-like PBMo-derived macrophages promoted the migration and invasion of ESCC cells. Our results demonstrated that TAM-like PBMo-derived macrophages significantly induced the migration and invasion of TE-8 and TE-9 cells (Figure 4A (i)-(ii), Supplementary Figure 5A (i)-(ii)). LY294002 or PD98059 inhibited the migration and invasion of TE-8 and TE-9 cells induced by TAM-like PBMo-derived macrophages (Figure 4B (i)-(ii), Supplementary Figure 5B (i)-(ii)). The neutralizing antibodies against CXCL8 and CXCR2 significantly suppressed the migration of TE-8 cells induced by TAM-like PBMo-derived macrophages, and the neutralizing antibodies against CXCR1 tended to reduce the migration of TE- 8 cells (Figure 4C (i)). These neutralizing antibodies significantly inhibited the invasion of TE-8 cells induced by TAM-like PBMo-derived macrophages (Figure 4C (ii)). The neutralizing antibodies against CXCR1, CXCR2 and CXCL8 also suppressed migration and invasion of TE-9 cells induced by TAMlike PBMo-derived macrophages (Supplementary Figure 5C (i)-(ii)).

\section{Not only TAMs but also cancer cells expressed CXCL8 in human ESCC tissue}

We examined the expression of CXCL8 in human ESCC tissue samples. Immunofluorescence demonstrated that a large fraction of the CXCL8-positive spindle cells co-expressed with the macrophage marker CD11b in the tumor nests and stroma of human ESCCs (Figure 5A, Supplementary Figure 6A). We observed CXCL8 expression in normal squamous epithelia and tumor nests, particularly in the invasive area, by immunohistochemistry. We observed various levels of CXCL8 immunoreactivities in cancer nests (negative, low and high) using corresponding normal squamous epithelia as a positive control (Figure 5B, Supplementary Figure 6B).

In non-neoplastic esophageal tissues, CXCR1 and CXCR2 were expressed in normal squamous epithelia and smooth muscle. In the tumor nests of human ESCC tissues, various levels of CXCR1 or CXCR2 were observed: low and high compared to the normal squamous epithelia as a positive control (Figure 5C and 5D).

\section{The expression levels of CXCL8 were closely correlated with clinicopathological factors and the prognosis of the ESCC patients}

We investigated whether the expression of CXCL8 had any significant association with clinicopathological factors of ESCC patients. We found that a high expression of CXCL8 was closely correlated with lymph node metastasis $(p=0.039)$, a high number of infiltrating CD204-positive macrophages $(p=0.043)$, and a high expression level of CXCR2 ( $p=0.043)$ (Table 1).

We next performed a prognostic study of 69 of the 70 ESCC patients (excluding the single patient who could not be followed). The disease-free survival (DFS) of the patients with a high expression of CXCL8 was significantly shorter compared to that of the patients with a negative or low expression of CXCL8 by log-rank test (the percent DFS after 2 years of the CXCL8 high, low, and negative groups were $50 \%, 89.5 \%$, and $92.85 \%$, respectively, high vs. low vs. negative, $p=0.0265$; high vs. low, $p=0.055$; high vs. negative, $p=0.013$ ) (Figure 5E (i)).

The overall survival of the patients was not significantly different among the negative-, low- and highexpression CXCL8 groups ( $p=0.25$ ) (Figure 5E (ii)). A significant independent impact of CXCL8 on the DFS rate was not revealed by the multivariate analysis in ESCC (Table 2). The expressions of CXCR1 or CXCR2 were not related to DFS or overall survival by log-rank test (Supplementary Figure 7).

\section{DISCUSSION}

CXCL8, also known as IL-8, belongs to the C-X-C motif chemokine family. The $C X C L 8$ gene encodes for a protein of 99 amino acids, and it is processed to active proteins of either 77 amino acids in nonimmune cells or 72 amino acids in immune cells. CXCR1 and CXCR2, G protein-coupled receptors, are known as CXCL8 receptors and are characterized by seven-transmembrane-spanning regions. CXCR1 is a receptor for CXCL6 and CXCL8, whereas CXCR2 is a receptor for not only CXCL8 but also CXCL1, CXCL2, CXCL3, CXCL5, CXCL6 and 


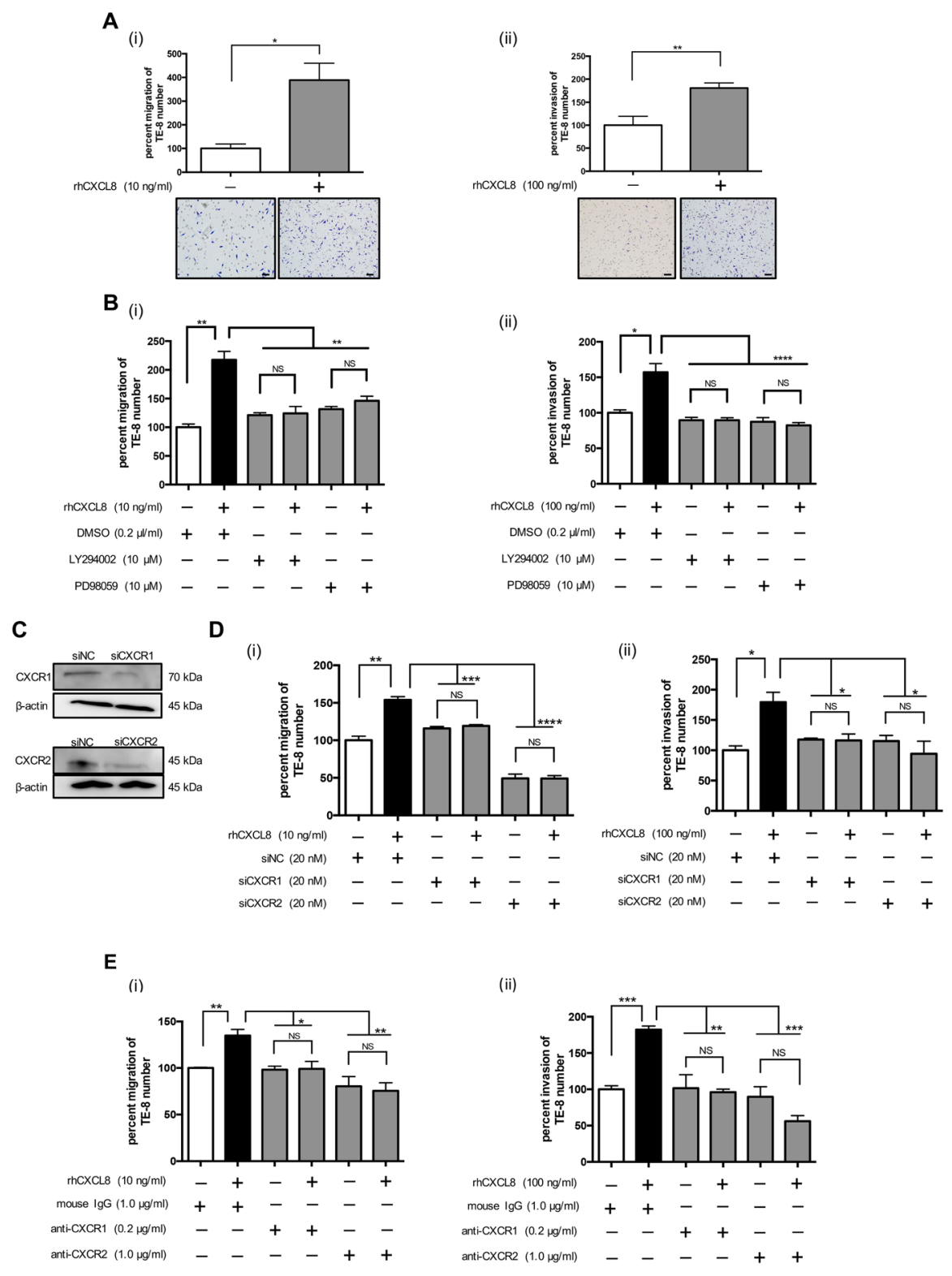

Figure 3: CXCL8 promoted the migration and invasion of the TE-8 cells. (A) (i) For the transwell migration assay, TE-8 cells were plated on the transwell in serum-free RPMI-1640 at $5.0 \times 10^{5}$ cells $/$ well. rhCXCL8 was added in the upper chamber at $10 \mathrm{ng} / \mathrm{ml}$. The cell inserts were set on 24-well plates in RPMI-1640 with 1\% FBS for $24 \mathrm{~h}$. The migrated cells on the underside of the membrane were stained by Diff-Quik and counted. The results are mean \pm SEM. Scale bar, $100 \mu \mathrm{m}$. (ii) For the transwell invasion assay, TE- 8 cells were seeded on a transwell coated with matrigel in serum-free RPMI-1640 at $5.0 \times 10^{5}$ cells/well. Recombinant human CXCL8 was added in the transwell at $100 \mathrm{ng} / \mathrm{ml}$. The cell inserts were set on 24-well plates in RPMI-1640 with 1\% FBS for $48 \mathrm{~h}$. The invaded cells on the underside of the membrane were stained by Diff-Quik and counted. (B) (i) TE-8 cells were plated on the upper chamber with or without rhCXCL8 at $10 \mathrm{ng} / \mathrm{ml}$ combined with the inhibitor against PI3K (LY294002, $10 \mu \mathrm{M}$ ) or MEK1/2 (PD98059, $10 \mu \mathrm{M})$. DMSO $(0.2 \mu \mathrm{l} / \mathrm{ml})$ was added to negative control. After $24 \mathrm{~h}$, the migrated cells were counted. (ii) TE-8 cells were plated on the upper transwell coated with matrigel. rhCXCL8 was added in the transwell combined with LY294002 $(10 \mu \mathrm{M})$ or PD98059 $(10 \mu \mathrm{M})$. DMSO $(0.2 \mu \mathrm{l} / \mathrm{ml})$ was added to negative control. After $48 \mathrm{~h}$, the invaded cells were counted. (C) TE-8 cells were transfected with $20 \mathrm{nM}$ siRNA targeting CXCR1 and CXCR2. siNC was transfected to TE-8 as negative control. Effective knockdown of CXCR1 and CXCR2 was confirmed by western blotting using antibodies against CXCR1 and CXCR2. (D) (i) CXCR1- or CXCR2-silenced TE-8 cells were plated on the upper transwell with rhCXCL8 at $10 \mathrm{ng} / \mathrm{ml}$. After $24 \mathrm{~h}$, the migrated cells were counted. (ii) CXCR1- or CXCR2-silenced TE-8 cells were plated on the upper transwell coated with matrigel. rhCXCL8 was added in the transwell at $100 \mathrm{ng} / \mathrm{ml}$. After $48 \mathrm{~h}$, the invaded cells were counted. (E) (i) TE-8 cells were plated on the upper transwell with rhCXCL8 at $10 \mathrm{ng} / \mathrm{ml}$ combined with the neutralizing antibody against CXCR1 $(0.2 \mu \mathrm{g} / \mathrm{ml})$ or CXCR2 $(1.0 \mu \mathrm{g} / \mathrm{ml})$. Mouse IgG was added to negative control. The concentrations of neutralizing antibodies were based on the manufacturer's instructions. (ii) TE-8 cells were plated on the upper transwell coated with matrigel. rhCXCL8 was added in the upper transwell at $100 \mathrm{ng} /$ $\mathrm{ml}$ combined with the neutralizing antibody against CXCR1 $(0.2 \mu \mathrm{g} / \mathrm{ml})$ or CXCR2 $(1.0 \mu \mathrm{g} / \mathrm{ml})$. Mouse IgG was added to negative control. After $48 \mathrm{~h}$, the invaded cells were counted. NS, not significant; ${ }^{*} p<0.05,{ }^{* * *} p<0.01,{ }^{* * *} p<0.001,{ }^{* * * * *} p<0.0001$. 

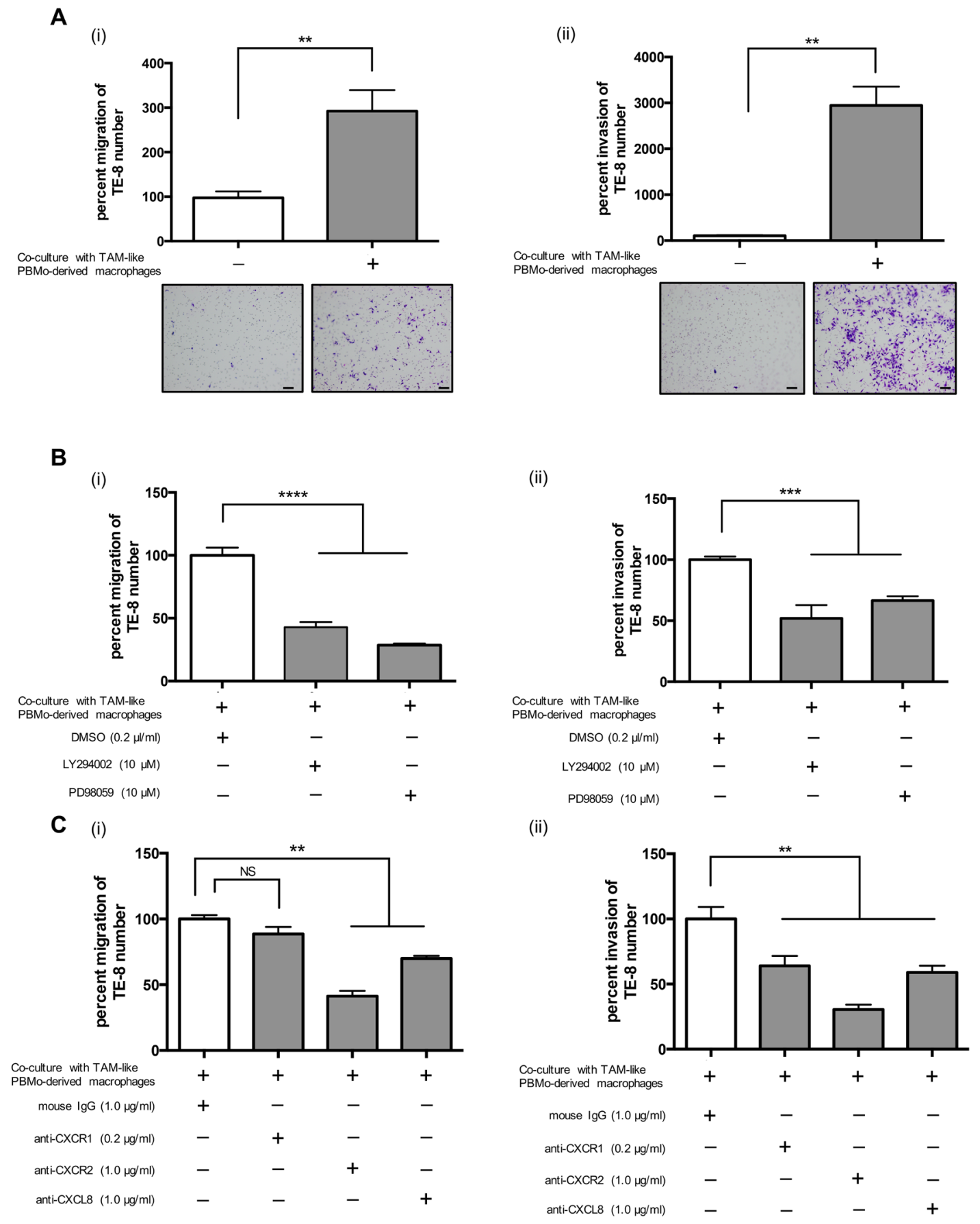

Figure 4: TAM-like PBMo-derived macrophages induced the migration and invasion of TE-8 cells by activating PI3K and MEK1/2 signals through CXCL8 and CXCR1/2 interaction. (A) PBMos $\left(1.0 \times 10^{5}\right.$ cells/well) were seeded on the lower chamber of 24-well plates with M-CSF $(25 \mathrm{ng} / \mathrm{ml})$ for 6 days to induce PBMo-derived macrophages, then incubated with $50 \%$ TE-8 CM to induce TAM-like PBMo-derived macrophages. After 2 days, the media were replaced with serum-free media. (i) TE- 8 cells were plated on the upper transwell at $5.0 \times 10^{5}$ cells/well and set on the plate. After $24 \mathrm{~h}$, the migrated cells were counted. (ii) TE- 8 cells were plated on the upper transwell coated with matrigel at $5.0 \times 10^{5}$ cells/well and set on the plate. After $48 \mathrm{~h}$, the invaded cells were counted. Scale bar, 100 $\mu \mathrm{m}$. (B) (i) TE-8 cells were plated on the upper transwell with the inhibitor against PI3K (LY294002, $10 \mathrm{nM}$ ) or MEK1/2 (PD98059, 10 $\mathrm{nM})$. DMSO $(0.2 \mu \mathrm{l} / \mathrm{ml})$ was added to negative control. After $24 \mathrm{~h}$, the migrated cells were counted. (ii) TE- 8 cells were plated on the upper matrigel-coated transwell with LY294002 $(10 \mathrm{nM})$ or PD98059 $(10 \mathrm{nM})$. DMSO $(0.2 \mu \mathrm{l} / \mathrm{ml})$ was added to negative control. After $48 \mathrm{~h}$, the invaded cells were counted. (C) (i) TE-8 cells were plated on the upper transwell with the neutralizing antibodies against CXCR1 (0.2 $\mu \mathrm{g} /$ $\mathrm{ml})$, CXCR2 $(1.0 \mu \mathrm{g} / \mathrm{ml})$ or CXCL8 $(1.0 \mu \mathrm{g} / \mathrm{ml})$. Mouse IgG was added to negative control. After $24 \mathrm{~h}$, the migrated cells were counted. The concentrations of neutralizing antibody were based on manufacturer's instructions. (ii) TE- 8 cells were plated on the upper matrigel-coated transwell with the neutralizing antibodies against CXCR1 $(0.2 \mu \mathrm{g} / \mathrm{ml})$, CXCR2 $(1.0 \mu \mathrm{g} / \mathrm{ml})$ or CXCL8 $(1.0 \mu \mathrm{g} / \mathrm{ml})$. Mouse IgG was added to negative control. After $48 \mathrm{~h}$, the invaded cells were counted. The results are mean \pm SEM. ${ }^{*} p<0.05,{ }^{* *} p<0.01,{ }^{* * *} p<0.001,{ }^{* * * *} p<0.0001$. 
A

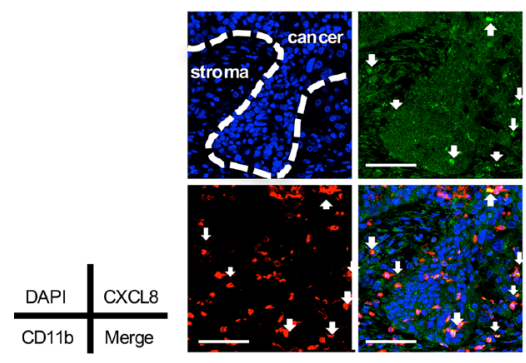

B

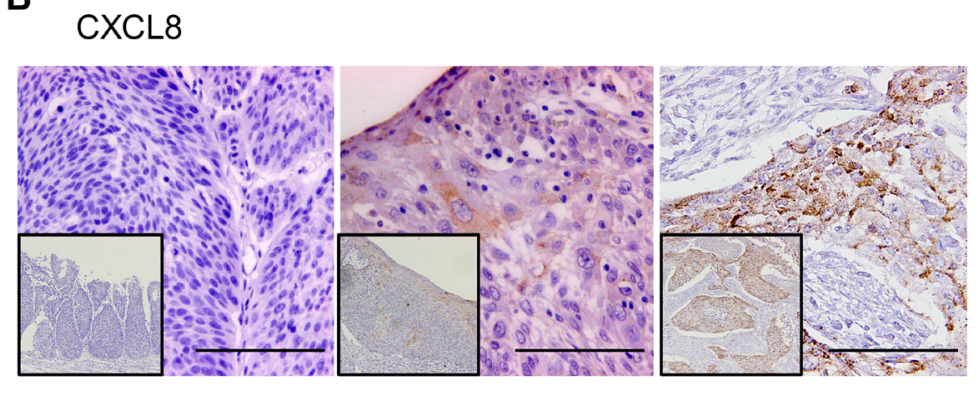

negative low high
C

\section{CXCR1}

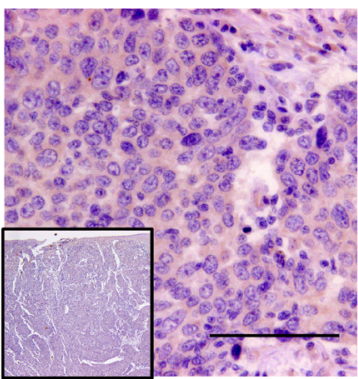

low

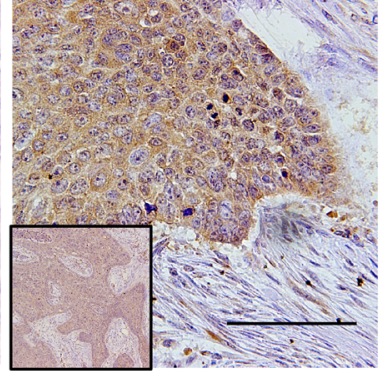

high

D

\section{CXCR2}

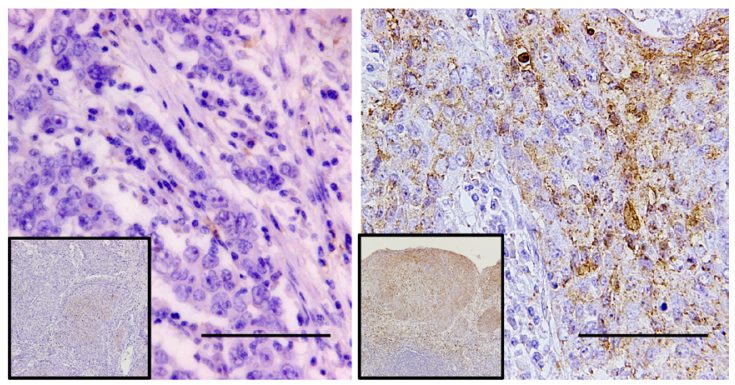

low
E

(i)

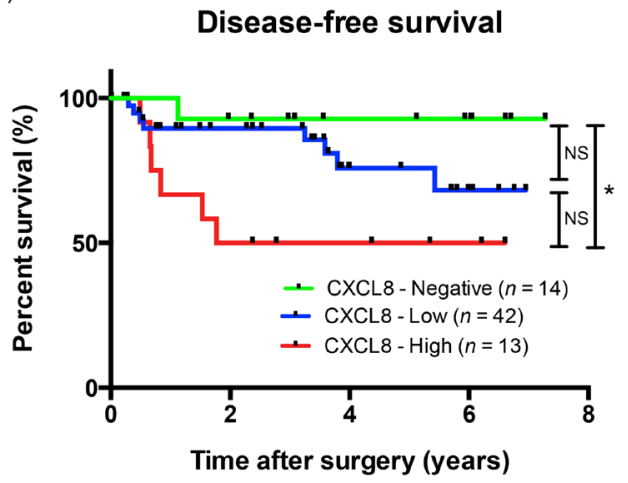

(ii)

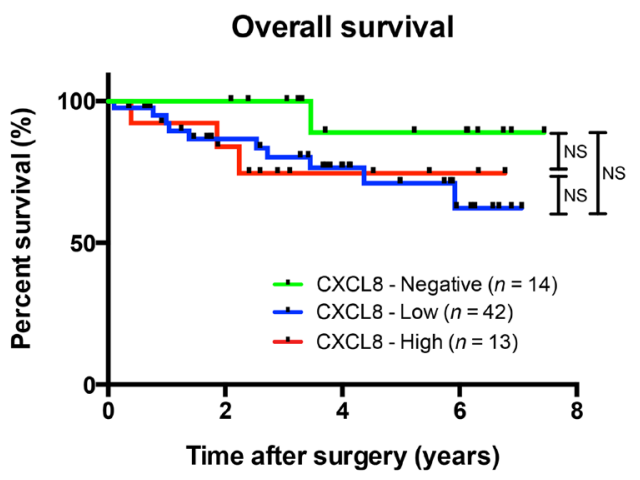

Figure 5: A high expression of CXCL8 in human ESCC tissues is associated with the poor prognosis of ESCC patients. (A) A double immunofluorescence analysis was performed using anti-CXCL8 (green) and anti-CD11b (red) antibodies on human ESCC tissue. Nuclei were stained with DAPI (blue). Not only CD11b-positive macrophages but also the cancer nest was stained by CXCL8 in human ESCC tissue. Scale bar, $100 \mu \mathrm{m}$. (B) Immunohistochemical staining for CXCL8 in human ESCC tissue. Typical images of CXCL8 are shown: negative (left), low-intensity (center) and high-intensity (right) compared to the corresponding normal esophageal epithelia. Scale bar, $100 \mu \mathrm{m}$. (C) Immunohistochemical staining for CXCR1 in human ESCC tissue. Typical images are shown: low-intensity (left) and high-intensity (right) compared to the corresponding normal esophageal epithelia. Scale bar, $100 \mu \mathrm{m}$. (D) Immunohistochemical staining for CXCR2 in human ESCC tissue. Typical images are shown: low-intensity (left) and high-intensity (right) compared to the corresponding normal esophageal epithelia. Scale bar, $100 \mu \mathrm{m}$. (E) Kaplan-Meier analysis of ESCC patients divided into three groups according to their expression of CXCL8: CXCL8-Negative group $(\mathrm{n}=14)$, CXCL8-Low group $(\mathrm{n}=43)$ and CXCL8-High group ( $\mathrm{n}=13)$. The log-rank test was performed to determine significance. ${ }^{*} p<0.05$. 
Table 1: Expression level of CXCL8 in ESCC and their correlation with clinicopathological data and infiltrating macrophages phenotypes

\begin{tabular}{cccc}
\hline \multirow{2}{*}{$\begin{array}{c}\text { Number of } \\
\text { cases }\end{array}$} & \multicolumn{3}{c}{ Expression of CXCL8 } \\
\cline { 2 - 4 } & Negative $(n=14)$ & Low $(n=43)$ & High $(n=13)$ \\
\hline
\end{tabular}

Age

$\begin{array}{llllll}<65 & 33 & 8 & 18 & 7 & 0.528 \\ \geq 65 & 37 & 6 & 25 & 6 & 6\end{array}$

Histological grade

$\begin{array}{cccccc}\text { HGIEN + WDSCC } & 16 & 4 & 9 & 3 & 0.986 \\ \text { MDSCC + PDSCC } & 54 & 10 & 34 & 10 & \end{array}$

Depth of tumor invasion $^{\mathrm{b}}$

$\begin{array}{ll}\mathrm{T} 1 & 49 \\ \mathrm{~T} 2+\mathrm{T} 3 & 21\end{array}$

12

31

6

0.072

$\mathrm{T} 2+\mathrm{T} 3$

21

2

12

7

Lymphatic vessel invasion $^{\mathrm{b}}$

$\begin{array}{lllll}\text { Negative } & 37 & 9 & 23 & 5 \\ \text { Positive } & 33 & 5 & 20 & 8\end{array}$

Blood vessel

invasion $^{\mathrm{b}}$

Negative
Positive

Lymph node metastasis $^{\mathrm{b}}$

$$
\begin{aligned}
& \text { Negative } \\
& \text { Positive }
\end{aligned}
$$

Stage

$$
\begin{aligned}
& 0+\mathrm{I} \\
& \mathrm{II}+\mathrm{III}+\mathrm{IV}
\end{aligned}
$$

CD68 positive cells ${ }^{\mathrm{d}}$

Low 35

High 35

CD163 positive cells ${ }^{\mathrm{d}}$

$\begin{array}{lll}\text { Low } & 35 & 9 \\ \text { High } & 35\end{array}$

CD204 positive cells ${ }^{\mathrm{d}}$

$\begin{array}{ll}\text { Low } & 34 \\ \text { High } & 36\end{array}$

$\begin{array}{ccc}10 & 21 & 3 \\ 4 & 22 & 10\end{array}$

$\begin{array}{ccc}22 & 4 & 0.213 \\ 21 & 9 & \\ 21 & 3 & 0.043^{*} \\ 22 & 10 & \end{array}$




\begin{tabular}{|c|c|c|c|c|c|}
\hline & \multirow{2}{*}{$\begin{array}{l}\text { Number of } \\
\text { cases }\end{array}$} & \multicolumn{3}{|c|}{ Expression of CXCL8 } & \multirow{2}{*}{$p$-value } \\
\hline & & Negative $(n=14)$ & Low $(n=43)$ & High $(n=13)$ & \\
\hline \multicolumn{6}{|l|}{ CXCR1 } \\
\hline Low & 41 & 9 & 24 & 8 & 0.831 \\
\hline High & 29 & 5 & 19 & 5 & \\
\hline \multicolumn{6}{|l|}{ CXCR2 } \\
\hline Low & 37 & 11 & 22 & 4 & $0.043^{*}$ \\
\hline High & 33 & 3 & 21 & 9 & \\
\hline
\end{tabular}

Data were analyzed by $\chi^{2}$-test. $p<0.05$ was considered statistically significant; ${ }^{*} p<0.05$

${ }^{a}$ Expression of CXCL8 in invasive area of ESCC tissue was divided into three groups according compared with the corresponding normal esophageal epithelia; Negative, Low and High.

${ }^{\mathrm{b}}$ According to the Japanese Classification of Esophageal Cancer. HGIEN, high-grade intraepithelial neoplasia; WDSCC, well-differentiated squamous cell carcinoma; MDSCC, moderately differentiated squamous cell carcinoma; PDSCC, poorly differentiated squamous cell carcinoma. T1a, tumor invades mucosa; T1b, tumor invades submucosa; T2, tumor invades muscularis propria; $\mathrm{T} 3$, tumor invades adventitia.

'According to the TNM classification by UICC.

${ }^{\mathrm{d}}$ The median values of CD68 positive, CD163 positive or CD204 positive macrophage numbers in cancer nests and stroma within the areas were used to divide the patients into low- and high-groups.

CXCL7 [21, 22]. Previous research demonstrated that CXCL8 binds to CXCR1 or CXCR2 and activates the PI3K-Akt and MEK1/2-Erk1/2 signaling pathways [23].

Recent studies have revealed that CXCL8 is upregulated and involved in the tumor progression of various human malignancies, including prostate cancer [24], breast cancer [25], gastric cancer [26], non-small lung cancer [27], colon cancer [28] and melanoma [29]. In human ESCCs, it was shown that a high concentration of CXCL8 in the serum or high levels of tissue expression in human ESCCs were associated with distant metastasis and poor prognosis [30]. However, no study has investigated the biological mechanism of a CXCL8-CXCR1/CXCR2 axis with the evaluation of the expression level of CXCL8 in TAMs that have invaded ESCC tissue. In the present study, we confirmed the expression level of CXCL8 in PBMo-derived macrophages, TAM-like PBMo-derived macrophages and ESCC cell lines, and the expression of CXCR1 and CXCR2 on the ESCC cell lines. Furudate et al. reported PBMo-derived macrophages treated with IL-4 expressed high level of various chemokines, including CXCL8, compared with PBMo-derived macrophages [31]. We also demonstrated that rhIL-4 up-regulated the expression level of $C X C L 8$ in PBMo-derived macrophages (Supplementary Figure 1). We then observed that rhCXCL8 induced the phosphorylation of Akt and Erk1/2 in human ESCC cells lines, which was similar to the results of previous studies of other cancer cell lines.

It has been revealed that CXCL8 promoted cell migration and/or invasion in human gastric cancer [32], colon cancer [33], breast cancer [34], hepatocellular carcinoma [35] and prostate cancer in vitro [36]. CXCL8 has also been reported to promote the proliferation of human colon cancer [37], prostate cancer [38] and breast cancer cells [34]. In the present study, we demonstrated for the first time that rhCXCL8 significantly induced the migration and invasion of human ESCC cell lines. rhCXCL8 had no effect on the proliferation of the human ESCC cells. As was reported regarding a papillary thyroid carcinoma cell line [39], CXCL8 might have different functions depending on the origin and histological types of cancer cells.

Earlier studies indicate that CXCL8 derived from TAMs is associated with tumor progression. Using a cytokine array analysis, Fang et al. [39] reported that the CXCL8 expression of TAMs which were isolated from human thyroid papillary cancer tissue was up-regulated in comparison with that of peripheral blood monocytes from healthy donors. They observed that rhCXCL8 promoted the invasion of papillary thyroid carcinoma cell lines, $\mathrm{K} 1$, TPC-1 and BCPAP in vitro. They also reported that BCPAP injected into tail vein of rhCXCL8-treated mice tended to metastasize to lung compared to the control mice [39].

Cao et al. demonstrated the CXCL8 derived from TAMs stimulated by leptin promoted the migration and invasion of human breast cancer cell lines in vitro and promoted tumor growth in vivo [40]. Tong et al. showed that CXCL8 from TAMs promoted the cell invasion of endometrial cancer through suppressed ER $\alpha$ expression, 
Table 2: Relationship between clinicopathological features of human squamous cell carcinoma and disease-free survival

\begin{tabular}{|c|c|c|c|c|c|c|}
\hline & \multicolumn{3}{|c|}{ Univariate analysis } & \multicolumn{3}{|c|}{ Multivariate analysis } \\
\hline & Number & $\begin{array}{c}\text { Median survival } \\
\text { (years) }\end{array}$ & $p$-value & HR & $95 \% \mathrm{CI}$ & $p$-value \\
\hline \multicolumn{7}{|l|}{ Age } \\
\hline$<65$ & 33 & 4.93 & 0.212 & & & \\
\hline$\geq 65$ & 36 & 6.15 & & & & \\
\hline \multicolumn{7}{|l|}{ Histological grade } \\
\hline HGIEN + WDSCC & 16 & 5.83 & 0.551 & & & \\
\hline MDSCC + PDSCC & 53 & 5.65 & & & & \\
\hline \multicolumn{7}{|l|}{$\begin{array}{l}\text { Depth of tumor } \\
\text { invasion }\end{array}$} \\
\hline $\mathrm{T} 1$ & 49 & 6.53 & $<0.001^{* * *}$ & 7.26 & $1.035-51.00$ & $0.046^{*}$ \\
\hline $\mathrm{T} 2+\mathrm{T} 3$ & 20 & 3.27 & & & & \\
\hline \multicolumn{7}{|l|}{$\begin{array}{l}\text { Lymphatic vessel } \\
\text { invasion }^{\mathrm{a}}\end{array}$} \\
\hline Negative & 37 & 6.43 & $0.002^{* *}$ & 1.19 & $0.219-6.463$ & 0.841 \\
\hline Positive & 32 & 55.3 & & & & \\
\hline \multicolumn{7}{|l|}{ Blood vessel invasion ${ }^{a}$} \\
\hline Negative & 43 & 5.84 & 0.181 & & & \\
\hline Positive & 26 & 5.11 & & & & \\
\hline \multicolumn{7}{|l|}{$\begin{array}{l}\text { Lymph node } \\
\text { metastasis }^{\mathrm{a}}\end{array}$} \\
\hline Negative & 43 & 6.48 & $<0.001^{* * *}$ & 0.57 & $0.046-7.155$ & 0.666 \\
\hline Positive & 26 & 4.16 & & & & \\
\hline \multicolumn{7}{|l|}{ Stage $^{b}$} \\
\hline $0+\mathrm{I}$ & 38 & 6.62 & $<0.001^{* * *}$ & 8.55 & $1.035-51.002$ & 0.185 \\
\hline $\mathrm{II}+\mathrm{III}+\mathrm{IV}$ & 31 & 4.34 & & & & \\
\hline \multicolumn{7}{|l|}{ CXCL8 } \\
\hline Negative & 14 & 7.01 & $0.026^{*}$ & 1.90 & $10.82-4.374$ & 0.133 \\
\hline Low & 42 & 5.68 & & & & \\
\hline High & 13 & 3.80 & & & & \\
\hline \multicolumn{7}{|l|}{ CXCR1 } \\
\hline Low & 40 & 5.56 & 0.524 & & & \\
\hline High & 29 & 5.58 & & & & \\
\hline
\end{tabular}

(Continued) 


\begin{tabular}{|c|c|c|c|c|c|c|}
\hline & \multicolumn{3}{|c|}{ Univariate analysis } & \multicolumn{3}{|c|}{ Multivariate analysis } \\
\hline & Number & $\begin{array}{c}\text { Median survival } \\
\text { (years) }\end{array}$ & $p$-value & HR & $95 \%$ CI & $p$-value \\
\hline \multicolumn{7}{|l|}{ CXCR2 } \\
\hline Low & 38 & 5.54 & 0.46 & & & \\
\hline High & 31 & 5.62 & & & & \\
\hline \multicolumn{7}{|c|}{ CD68 positive cells ${ }^{\mathrm{c}}$} \\
\hline Low & 35 & 5.96 & $0.034^{*}$ & 3.85 & $0.511-29.07$ & 0.191 \\
\hline High & 34 & 5.02 & & & & \\
\hline \multicolumn{7}{|c|}{ CD163 positive cells ${ }^{\mathrm{c}}$} \\
\hline Low & 35 & 6.0 & 0.134 & & & \\
\hline High & 34 & 5.21 & & & & \\
\hline \multicolumn{7}{|c|}{ CD204 positive cells ${ }^{\mathrm{c}}$} \\
\hline Low & 34 & 6.2 & $0.025^{*}$ & 0.196 & $0.22-1.786$ & 0.148 \\
\hline High & 35 & 5.0 & & & & \\
\hline
\end{tabular}

Disease free survival was estimated by Kaplan-Meier method compared by log-rank test. $p<0.05$ was considered statistically significant; ${ }^{*} p<0.05 ;{ }^{* *} p<0.01 ;{ }^{* * *} p<0.001$.

${ }^{a}$ According to the Japanese Classification of Esophageal Cancer. HGIEN, high-grade intraepithelial neoplasia; WDSCC, well-differentiated squamous cell carcinoma; MDSCC, moderately differentiated squamous cell carcinoma; PDSCC, poorly differentiated squamous cell carcinoma. T1a, tumor invades mucosa; T1b, tumor invades submucosa; T2, tumor invades muscularis propria; T3, tumor invades adventitia.

${ }^{\mathrm{b}}$ According to the TNM classification by UICC.

${ }^{\mathrm{c}}$ The median values of CD68 positive, CD163 positive or CD204 positive macrophage numbers in cancer nests and stroma within the areas were used to divide the patients into low- and high-groups.

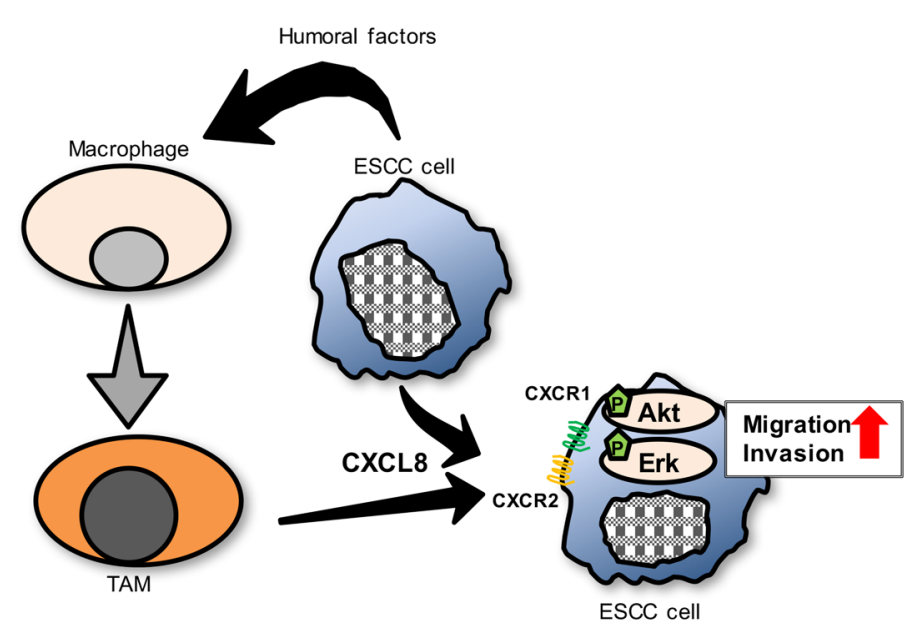

Figure 6: A proposed model of the interaction between ESCC cells and TAMs through CXCL8 in tumor microenvironment. Many humoral factors, including IL-4, induced macrophages into TAMs. Then, expression level of CXCL8 was upregulated in TAMs. CXCL8 secreted from TAMs, as well as from ESCC cells, contributed ESCC cells' migration and invasion by activating Akt and Erk1/2 signals through CXCR1/CXCR2 of ESCC cells. 
which was related to poor survival [41]. In the present study, we demonstrated that CXCL8 derived from TAMlike PBMo-derived macrophages induced cell migration and invasion by indirect co-culture with ESCC cell lines, and these were significantly suppressed by neutralizing antibodies against CXCR1, CXCR2 or CXCL8. These observations indicate that CXCL8 derived from TAMs has important roles in the migration and invasion of ESCC cells.

CXCR2 is known as multiple C-X-C motif chemokine receptor. Wang et al. showed that CXCL1, one of the ligands to CXCR2, is involved in the migration and invasion of gastric cancer cells in vitro [42]. Using immunohistochemistry, they also showed that the expression level of CXCL1 in human gastric cancer tissues was associated with lymph node metastasis and TNM classification. Zhao et al. reported that the CXCL5CXCR2 axis promoted the migration of human colorectal cancer cells in vitro and increased liver metastasis from the injected tumor of mice spleen in vivo [43]. Neutralizing antibody against CXCR2 demonstrated a stronger suppressive effect on the phenotypes of ESCC cell lines induced by TAM-like PBMo-derived macrophages compare to the antibodies against CXCR1 and CXCL8. Targeting CXCR2 to suppress the migration and invasion of ESCC cells by inhibiting the function of not only CXCL8 but also other C-X-C motif chemokines derived from TAMs may be a rather effective therapy for ESCC.

Using immunohistochemistry, Ogura et al. showed that high expression levels of CXCL8 and CXCR2 in human ESCC tissue were associated with poor prognosis [44]. They classified ESCC tissues into two groups, negative and positive, based on the product of the intensity of immunostaining and the percentage of positive tumor cells expressing CXCL8 and CXCR2. In the present study, we classified the expression level of CXCL8 into three groups: negative, low, and high. As low-dose CXCL8 was reported to induce the migration and invasion of human gastric cancer cell lines [45], we suspected that even a low expression level of CXCL8 would be associated with tumor progression. Our investigation revealed that a high expression level of CXCL8 by ESCC tissue was significantly associated with DFS, lymph node metastasis, a high expression level of CXCR2, and the invasion of high numbers of CD204-positive macrophages. Our findings indicated that CXCL8 derived from not only TAMs but also ESCC cells contributed to the progression of ESCC. In this study, although the combination of a high expression level of CXCL8 and that of CXCR2 was not significantly associated with poor prognosis, the CXCL8 expression level was significantly related to that of CXCR2. Using immunohistochemistry in human ESCC, Sui et al. reported that a high expression of CXCR2 was correlated with poor survival [46]. In our study, the expression levels of both CXCR1 and CXCR2 in cancer nests were not related to prognosis. Notably, this study had a limited number of patients for the evaluation of the interaction between the expression levels of receptors and prognosis.

In conclusion, we demonstrated that CXCL8 derived from TAM-like PBMo-derived macrophages promoted the migration and invasion of ESCC cell lines via the phosphorylation of Akt and Erk1/2 through CXCR1 and CXCR2 in vitro. A high expression level of CXCL8 in TAMs and ESCC cancer cells was strongly associated with poor prognosis through lymph node metastasis. Targeting the CXCL8-CXCR1/CXCR2 axis in human ESCC tissues might be an effective new therapy (Figure 6).

\section{MATERIALS AND METHODS}

\section{Cell line and cell culture}

Three ESCC cell lines (TE-8, TE-9 and TE15) were obtained from the RIKEN BioResource Center (Tsukuba, Japan) [47]. Het-1A is a normal human squamous esophageal cell line transfected nontumorigenic SV40-T. We purchased it from American Type Culture Collection ${ }^{\circledR}$ (Manassas, VA, USA) [48]. The individuality of the TE series ESCC cell lines was confirmed by a short tandem repeat (STR) analysis at RIKEN and at the Cell Resource Center for Biomedical Research, Institute of Development, Aging and Cancer, Tohoku University in 2009 and 2010 (Sendai, Japan). All TE cells were confirmed to be mycoplasma-negative by a Venor $^{\circledR}$ Gem Classic Mycoplasma Detection kit (Minerva Biolabs, Berlin, Germany). Het-1A was confirmed not to have human pathogenic virus using PCR-based assay for HIV, HepB, HPV, EBV and CMV. We maintained the ESCC cell lines in RPMI-1640 (Wako, Osaka, Japan) with 10\% fetal bovine serum (FBS) (Sigma-Aldrich, St Louis, MO, USA) and 1\% antibiotic-antimycotic (Invitrogen, Carlsbad, CA). Het-1A cell line was cultured in BEGM ${ }^{\mathrm{TM}}$ (Lonza, Walkersvile, MD, USA). The conditioned medium of TE series (TECM) and Het-1A CM was prepared by plating $5 \times 10^{6}$ tumor cells in $10 \mathrm{ml}$ of complete medium in 100-mm dishes for $24 \mathrm{~h}$, and the medium was then changed to complete DMEM (Wako) with $10 \%$ human AB serum (Lonza, Walkersville, MD). After 2 days, the supernatants were harvested, centrifuged, and stored in aliquots at $-80^{\circ} \mathrm{C}$.

\section{Macrophage culture}

Peripheral blood mononuclear cells (PBMCs) were obtained from healthy volunteer donors after informed consent was obtained. $\mathrm{CD} 14^{+}$peripheral blood monocytes (PBMos) were purified from PBMCs by positive selection using the auto MACS ${ }^{\circledR}$ Pro Separator (Miltentyi Biotec, Bergisch Gladbach, Germany). PBMos were cultured with 
macrophage-colony stimulating factor (M-CSF) (25 ng/ $\mathrm{ml}$; R\&D Systems, Minneapolis, MN) for 6 days to induce macrophages, then cultured for 2 days added $50 \%$ TECMs to induce TAM-like polarization.

\section{Tissue samples}

A total of 70 human ESCC tissue samples excised from 2005 to 2010 at Kobe University Hospital (Kobe, Japan) were used in this study. Informed consent for the use of tissue samples was obtained from all patients, and the study was approved by the Kobe University Institutional Review Board. We analyzed the histological and clinicopathological information using the Japanese Classification of Esophageal Cancer proposed by the Japan Esophageal Society and the TNM classification of the Union for International Cancer Control.

\section{Immunofluorescence}

TE cells were seeded onto coverslips overnight and fixed with $4 \%$ paraformaldehyde phosphate buffer solution (Wako) and incubated with rabbit monoclonal antibody against CD11b (1:100, \#ab52478, Abcam, Cambridge, UK), mouse monoclonal antibody against CXCL8 (1:20, \#ab18672, Abcam), rabbit polyclonal antibody against CXCR1 (1:50, \#sc-988, Santa Cruz Biotechnology, Dallas, TX) and CXCR2 (1:50, \#sc-682, Santa Cruz) at $4^{\circ} \mathrm{C}$ overnight. Alexa Fluor ${ }^{\circledR}$ 488-conjugated donkey anti-mouse secondary antibody (Jackson ImmunoResearch Laboratories, West Grove, PA), Cy3conjugated donkey anti-rabbit IgG secondary antibody (Jackson ImmunoResearch Laboratories) and DyLight 488-conjugated goat anti-mouse secondary antibody (Vector Laboratories, Burlingame, CA) were incubated at room temperature for $1 \mathrm{~h}$. The nuclei were stained with DAPI (Wako). Images were taken with a Zeiss LSM 700 laser-scanning microscope and analyzed using the LSM software ZEN 2009 (Carl Zeiss, Oberkochen, Germany).

\section{Reverse transcription-PCR (RT-PCR) and quantitative RT-PCR (qRT-PCR)}

Total RNA was extracted from cultured cells using the RNeasy Mini Kit (Qiagen, Hilden, Germany). RT-PCR amplifications of $C X C L 8, C X C R 1, C X C R 2$ and the internal control gene $G A P D H$ were performed. PCR products were subjected to electrophoresis in a $2 \%$ agarose gel. The qRTPCR amplifications of $C X C L 8$ and the internal control gene $G A P D H$ were performed using the ABI StepOne Real-time PCR system (Applied Biosystems, Foster City, CA). The threshold cycle $(\mathrm{Ct})$ values were determined by plotting the observed fluorescence against the cycle number. $\mathrm{Ct}$ values were analyzed using the comparative threshold cycle method and normalized to those of GAPDH.
The relative gene expression levels were estimated using following formula: relative expression $=2-(\mathrm{Ct}$ [target gene] - $\mathrm{Ct}$ [GAPDH]). The primers were designed as follows: GAPDH, 5'-ACC ACA GTC CAT GCC ATC AC-3' / 5'-TCC ACC ACC CTG TTG CTG TA-3'; CXCL8, 5'-AAA CCA CCG GAA GGA ACC AT-3' / 5'CCT TCA CAC AGA GCT GCA GAA A-3'; CXCR1, 5'CTG CAG CTC CTA CTG TTG G-3' / 5'-TTC ATC TGC AGC TGG CAT G-3'; CXCR2, 5'-GGT TGC CAA GCC TTG TCT GA-3' / 5'-AGG GAG TTC ACA TGC GCC T-3'

\section{Western blotting}

Cells were lysed on ice with a cell lysis buffer (50 $\mathrm{mM}$ Tris- $\mathrm{HCl} \mathrm{pH} 7.5,125 \mathrm{mM} \mathrm{NaCl}, 0.1 \%$ Triton X-100 and $5 \mathrm{mM}$ EDTA) or NP40 cell lysis buffer (Thermo Fisher Scientific, Waltham, MA) containing both $1 \%$ protease inhibitor and $1 \%$ phosphatase inhibitor cocktail (Sigma-Aldrich). The resulting lysates were separated on $5-20 \%$ sodium dodecyl sulfate polyacrylamide gels, transferred to a membrane with iBlot Gel Transfer Stack (Invitrogen). The membrane was blocked with 5\% skim milk and then incubated with primary and secondary antibodies. The protein bands were detected with ImmunoStar Reagents (Wako).

The primary antibodies were as follows. Rabbit antibody against CXCR1 (1:50, \#sc-988, Santa Cruz), rabbit antibody against CXCR2 (1:50; \#sc-682, Santa Cruz), and the following (all from Cell Signaling Technology, Beverly, MA): rabbit antibody against phosphorylated Akt (Ser473, 1:500, \#4060), rabbit antibody against phosphorylated Akt (Thr308, 1:500, \#2965), rabbit antibody against non-phosphorylated Akt (1:1000, \#9272), rabbit antibody against phosphorylated Erk1/2 (Thr202/Tyr204, 1:500, \#9101), rabbit antibody against non-phosphorylated Erk1/2 (1:500,\#9102), rabbit antibody against $\beta$-actin (1:1000, \#4970).

The following secondary antibodies were both from GE Healthcare Life Sciences, Little Chalfont, UK: horseradish peroxidase (HRP)-linked sheep anti-mouse IgG (NA931V, NA931) and HRP-linked donkey antirabbit IgG (NA934V).

\section{Cell growth assay and survival assay}

Cells were seeded on 96-well plates at $1.0 \times 10^{4}$ per well with serum-free RPMI-1640 or seeded at $5.0 \times 10^{3}$ per well with $1 \% \mathrm{FBS}$, followed by incubation at $37^{\circ} \mathrm{C}$. The cells were then treated with $0,1,10$ or $100 \mathrm{ng} / \mathrm{ml}$ recombinant human CXCL8 (rhIL-8; R\&D Systems). After 0, 24, 48 and $96 \mathrm{~h}$, we applied CellTiter ${ }^{\circledR} 96$ Aqueous One Solution Reagent (Promega, Madison, WI). The absorbance was measured by a microplate reader (Infinite 200 PRO; Tecan, Mannedorf, Switzerland) at $492 \mathrm{~nm}$. 


\section{Transwell migration assay and invasion assay}

For the migration assay, TE cells $\left(5.0 \times 10^{5}\right.$ cells/ well) in serum-free media were plated on the upper transwell inserts with an $8-\mu \mathrm{m}$ pore filter (BD Falcon, Lincoln Park, NY) in 24-well plates. For the invasion assay, TE cells $\left(5.0 \times 10^{5}\right.$ cells/ well $)$ in serum-free media were plated on the inserts of a Corning ${ }^{\circledR}$ BioCoat $^{\mathrm{TM}}$ Matrige ${ }^{\circledR}$ Invasion Chamber (Corning, Tewksbury, MA) in 24-well plates. Medium containing $1 \%$ FBS was added in the lower chamber. Recombinant human CXCL8, inhibitors, or neutralizing antibodies were added in the upper chamber and incubated at $37^{\circ} \mathrm{C}$. After $24 \mathrm{~h}$ or 48 $\mathrm{h}$, the cells were stained with Diff-Quik (Sysmex, Kobe, Japan), and then the cells on the upper surface of the membrane were removed with a cotton swab and airdried. Five images at $100 \times$ magnification were obtained from each membrane with a CCD camera, and the number of cells was counted. The inhibitors against PI3K (LY294002) and MEK1/2 (PD98059) were purchased from Cell SignaIing Technology. The neutralizing antibodies were as follows (all from Abcam): normal mouse IgG (\#ab188776); mouse antibody against CXCR1 (\#ab10400); mouse antibody against CXCR2 (\#ab10401); mouse antibody against CXCL8 (\#ab18672).

\section{Co-culture transwell migration assay and invasion assay}

PBMos $\left(1.0 \times 10^{5}\right.$ cells/well $)$ were seeded on the lower chamber in 24-well plates with M-CSF (25 ng/ $\mathrm{ml}$; R\&D Systems) for 6 days to induce macrophages, and then incubated with $50 \%$ TECMs to induce TAMlike macrophages. After 2 days, the media were replaced with serum-free media. TE cells $\left(5.0 \times 10^{5}\right.$ cells/well $)$ in serum-free media plated on the upper transwell inserts. Transwell migration and invasion assays were performed as described above.

\section{CXCR1 and $C X C R 2$ knockdown by small interfering RNA}

Cancer cell lines were transfected with $20 \mathrm{nM}$ small interfering RNA (siRNA) targeting human CXCRI (IL$8 R A$ siRNA, sc-40026, Santa Cruz) and CXCR2 (IL-8RB siRNA, sc-40028, Santa Cruz) using Lipofectamine ${ }^{\circledR}$ RNAiMAX (Invitrogen). Control siRNA (Sigma-Aldrich) was used as the negative control.

\section{Enzyme-linked immunosorbent assay (ELISA)}

PBMo-derived macrophages, TAM-like macrophages and ESCC cell lines were cultured in 24well plates $\left(1 \times 10^{5}\right.$ cells/well $)$ with RPMI-1640 10\% FBS and $1 \%$ antibiotic-antimycotic. After $48 \mathrm{~h}$, the CXCL8 levels in the cell culture supernatants were determined by the Quantikine ELISA Human IL-8 immunoassay (R\&D
Systems) according to the manufacturer's instructions. The optical density of each well was determined by the Infinite 200 PRO microplate reader at $492 \mathrm{~nm}$. The CXCL8 concentration of each sample was calculated using a standard curve and the measured absorbance.

\section{Immunohistochemistry}

Antigen retrieval of $10 \%$ formalin-fixed and paraffin-embedded tissues was heat-induced in citrate buffer, $\mathrm{pH}$ 6.0. Immunohistochemistry was performed using EnVision Dual Link System-HRP, 3.3'-diaminobenzidine (Dako Cytomation, Glostrup, Denmark). The following antibodies were used to detect cellular antigens: mouse antibody against CXCL8 (1:20, \#ab18672, Abcam), mouse antibody against CXCR1 (1:50, \#ab10400, Abcam), mouse antibody against CXCR2 (1:20, \#22106, LifeSpan BioSciences, Seattle, WA). We evaluated the immunohistochemical staining intensity of the cancer nests as a qualitative score compared to that of corresponding normal esophageal epithelium: CXCL8, negative, low, and high; CXCR1, low and high; CXCR2, low and high.

\section{Statistical analysis}

All experiments were performed in triplicate and independently conducted three times. The results are expressed as mean \pm SEM, and statistical significance was analyzed by two-sided Student's $t$-test or one-way ANOVA. The relationships between clinicopathological factors and immunohistochemical results were estimated by $\chi^{2}$ test. Disease-free and overall survival curves were estimated by the Kaplan-Meier method compared by logrank test. The significance of parameters in a multivariate analysis was tested using the Cox proportional hazard regression model. A $p$-value $<0.05$ was considered significant. Statistical analyses were carried out using SPSS Statistics ver. 22 (IBM, Chicago, IL).

\section{Abbreviations}

Ct, threshold cycle; CXCL8, C-X-C chemokine ligand 8; DFS, disease-free survival; DMEM, Dulbecco's Modified Eagle's Medium; ESCC, esophageal squamous cell carcinoma; HRP, horseradish peroxidase; IL-4, interleukin 4; IL-8, interleukin 8; M-CSF, macrophagecolony stimulating factor; OS, overall survival; PBMC, peripheral blood mononuclear cell; PBMo, peripheral blood monocyte; TECM, conditioned medium of the TE series ESCC cell line.

\section{Author contributions}

$\mathrm{MH}, \mathrm{YK}, \mathrm{NT}, \mathrm{NH}, \mathrm{HK}$ and $\mathrm{KS}$ conceived and performed the experiments. MH, YK and HY analyzed the data and wrote the manuscript. NU, MN and MS 
prepared the tissue samples and performed the histological classification.

\section{ACKNOWLEDGMENTS}

This work was supported by Grants-in-Aid for Scientific Research (C-26460418) and (JP17K08693) and for Young Scientists (JP16K21159) from the Japan Society for the Promotion of Science. We thank Atsuko Kawashima, Yumi Hashimoto, Nobuo Kubo, Miki Yamazaki and Shuichi Matsumoto for their excellent technical assistance.

\section{CONFLICTS OF INTEREST}

The authors declare no conflicts of interest.

\section{REFERENCES}

1. Li H, Fan X, Houghton J. Tumor microenvironment: the role of the tumor stroma in cancer. J Cell Biochem. 2007; 101: 805-15. https://doi.org/10.1002/jcb.21159.

2. Binnemars-Postma K, Storm G, Prakash J. Nanomedicine strategies to target tumor-associated macrophages. Int J Mol Sci. 2017; 18. https://doi.org/10.3390/ijms18050979.

3. Zheng X, Turkowski K, Mora J, Brune B, Seeger W, Weigert A, Savai R. Redirecting tumor-associated macrophages to become tumoricidal effectors as a novel strategy for cancer therapy. Oncotarget. 2017; 8: 48436-52. https://doi.org/10.18632/oncotarget.17061.

4. Komohara Y, Fujiwara Y, Ohnishi K, Takeya M. Tumorassociated macrophages: potential therapeutic targets for anti-cancer therapy. Adv Drug Deliv Rev. 2016; 99: 180-5. https://doi.org/10.1016/j.addr.2015.11.009.

5. Hu H, Hang JJ, Han T, Zhuo M, Jiao F, Wang LW. The M2 phenotype of tumor-associated macrophages in the stroma confers a poor prognosis in pancreatic cancer. Tumour Biol. 2016; 37: 8657-64. https://doi.org/10.1007/ s13277-015-4741-z.

6. Zhang M, He Y, Sun X, Li Q, Wang W, Zhao A, Di W. A high M1/M2 ratio of tumor-associated macrophages is associated with extended survival in ovarian cancer patients. J Ovarian Res. 2014; 7: 19. https://doi. org/10.1186/1757-2215-7-19.

7. Zhang C, Hu X, Liu XY, Liang P, Zhang J, Cao L, Wang ZL, Liu HR, Yin XG, Dong CY, Wang LM. Effect of tumor-associated macrophages on gastric cancer stem cell in omental milky spots and lymph node micrometastasis. Int J Clin Exp Pathol. 2015; 8: 13795-805.

8. Miyasato Y, Shiota T, Ohnishi K, Pan C, Yano H, Horlad H, Yamamoto Y, Yamamoto-Ibusuki M, Iwase H, Takeya M, Komohara Y. High density of CD204-positive macrophages predicts worse clinical prognosis in patients with breast cancer. Cancer Sci. 2017; 108: 1693-700. https://doi. org/10.1111/cas.13287.
9. Malhotra GK, Yanala U, Ravipati A, Follet M, Vijayakumar M, Are C. Global trends in esophageal cancer. J Surg Oncol. 2017; 115: 564-79. https://doi.org/10.1002/jso.24592.

10. Tachimori Y, Ozawa S, Numasaki H, Fujishiro M, Matsubara H, Oyama T, Shinoda M, Toh Y, Udagawa H, Uno T. Comprehensive registry of esophageal cancer in Japan, 2009. Esophagus. 2016; 13: 110-37. https://doi. org/10.1007/s10388-016-0531-y.

11. Amanuma Y, Ohashi S, Itatani Y, Tsurumaki M, Matsuda S, Kikuchi O, Nakai Y, Miyamoto S, Oyama T, Kawamoto T, Whelan KA, Nakagawa H, Chiba T, et al. Protective role of ALDH2 against acetaldehyde-derived DNA damage in oesophageal squamous epithelium. Sci Rep. 2015; 5: 14142. https://doi.org/10.1038/srep14142.

12. Gu H, Gong D, Ding G, Zhang W, Liu C, Jiang P, Chen $\mathrm{S}$, Chen Y. A variant allele of ADH1B and ALDH2, is associated with the risk of esophageal cancer. Exp Ther Med. 2012; 4: 135-40. https://doi.org/10.3892/ etm.2012.547.

13. Shigeoka M, Urakawa N, Nakamura T, Nishio M, Watajima T, Kuroda D, Komori T, Kakeji Y, Semba S, Yokozaki H. Tumor associated macrophage expressing CD204 is associated with tumor aggressiveness of esophageal squamous cell carcinoma. Cancer Sci. 2013; 104: 1112-9. https://doi.org/10.1111/cas.12188.

14. Urakawa N, Utsunomiya S, Nishio M, Shigeoka M, Takase N, Arai N, Kakeji Y, Koma Y, Yokozaki H. GDF15 derived from both tumor-associated macrophages and esophageal squamous cell carcinomas contributes to tumor progression via Akt and Erk pathways. Lab Invest. 2015; 95: 491-503. https://doi.org/10.1038/labinvest.2015.36.

15. Takase N, Koma Y, Urakawa N, Nishio M, Arai N, Akiyama H, Shigeoka M, Kakeji Y, Yokozaki H. NCAM- and FGF-2mediated FGFR1 signaling in the tumor microenvironment of esophageal cancer regulates the survival and migration of tumor-associated macrophages and cancer cells. Cancer Lett. 2016; 380: 47-58. https://doi.org/10.1016/j. canlet.2016.06.009.

16. Todorovic-Rakovic N, Milovanovic J. Interleukin-8 in breast cancer progression. J Interferon Cytokine Res. 2013; 33: 563-70. https://doi.org/10.1089/jir.2013.0023.

17. Xiao YC, Yang ZB, Cheng XS, Fang XB, Shen T, Xia CF, Liu P, Qian HH, Sun B, Yin ZF, Li YF. CXCL8, overexpressed in colorectal cancer, enhances the resistance of colorectal cancer cells to anoikis. Cancer Lett. 2015; 361: 22-32. https://doi.org/10.1016/j.canlet.2015.02.021.

18. Boldrini L, Gisfredi S, Ursino S, Lucchi M, Mussi A, Basolo F, Pingitore R, Fontanini G. Interleukin-8 in nonsmall cell lung carcinoma: relation with angiogenic pattern and p53 alterations. Lung Cancer. 2005; 50: 309-17. https:// doi.org/10.1016/j.lungcan.2005.07.002.

19. Shi J, Li YJ, Yan B, Wei PK. Interleukin-8: a potent promoter of human lymphatic endothelial cell growth in gastric cancer. Oncol Rep. 2015; 33: 2703-10. https://doi. org/10.3892/or.2015.3916. 
20. Huang S, Mills L, Mian B, Tellez C, McCarty M, Yang XD, Gudas JM, Bar-Eli M. Fully humanized neutralizing antibodies to interleukin-8 (ABX-IL8) inhibit angiogenesis, tumor growth, and metastasis of human melanoma. Am J Pathol. 2002; 161: 125-34. https://doi.org/10.1016/ s0002-9440(10)64164-8.

21. Liu Q, Li A, Tian Y, Wu JD, Liu Y, Li T, Chen Y, Han $\mathrm{X}, \mathrm{Wu} \mathrm{K}$. The CXCL8-CXCR1/2 pathways in cancer. Cytokine Growth Factor Rev. 2016; 31: 61-71. https://doi. org/10.1016/j.cytogfr.2016.08.002.

22. Gales D, Clark C, Manne U, Samuel T. The Chemokine CXCL8 in carcinogenesis and drug response. ISRN Oncol. 2013; 2013: 859154. https://doi.org/10.1155/2013/859154.

23. Waugh DJ, Wilson C. The interleukin- 8 pathway in cancer. Clin Cancer Res. 2008; 14: 6735-41. https://doi. org/10.1158/1078-0432.CCR-07-4843.

24. Araki S, Omori Y, Lyn D, Singh RK, Meinbach DM, Sandman Y, Lokeshwar VB, Lokeshwar BL. Interleukin-8 is a molecular determinant of androgen independence and progression in prostate cancer. Cancer Res. 2007; 67: 685462. https://doi.org/10.1158/0008-5472.CAN-07-1162.

25. Singh JK, Simoes BM, Clarke RB, Bundred NJ. Targeting IL-8 signalling to inhibit breast cancer stem cell activity. Expert Opin Ther Targets. 2013; 17: 1235-41. https://doi. org/10.1517/14728222.2013.835398.

26. Shi J, Wei PK. Interleukin-8: a potent promoter of angiogenesis in gastric cancer. Oncol Lett. 2016; 11: 104350. https://doi.org/10.3892/ol.2015.4035.

27. Millar HJ, Nemeth JA, McCabe FL, Pikounis B, Wickstrom E. Circulating human interleukin-8 as an indicator of cancer progression in a nude rat orthotopic human non-small cell lung carcinoma model. Cancer Epidemiol Biomarkers Prev. 2008; 17: 2180-7. https://doi.org/10.1158/1055-9965. EPI-07-2915.

28. Lee YS, Choi I, Ning Y, Kim NY, Khatchadourian V, Yang D, Chung HK, Choi D, LaBonte MJ, Ladner RD, Nagulapalli Venkata KC, Rosenberg DO, Petasis $\mathrm{NA}$, et al. Interleukin- 8 and its receptor CXCR2 in the tumour microenvironment promote colon cancer growth, progression and metastasis. Br J Cancer. 2012; 106: 1833 41. https://doi.org/10.1038/bjc.2012.177.

29. Singh S, Singh AP, Sharma B, Owen LB, Singh RK. CXCL8 and its cognate receptors in melanoma progression and metastasis. Future Oncol. 2010; 6: 111-6. https://doi. org/10.2217/fon.09.128.

30. Krzystek-Korpacka M, Matusiewicz M, Diakowska D, Grabowski K, Blachut K, Konieczny D, KustrzebaWojcicka I, Terlecki G, Banas T. Elevation of circulating interleukin- 8 is related to lymph node and distant metastases in esophageal squamous cell carcinomas--implication for clinical evaluation of cancer patient. Cytokine. 2008; 41: 232-9. https://doi.org/10.1016/j.cyto.2007.11.011.

31. Furudate S, Fujimura T, Kakizaki A, Hidaka T, Asano M, Aiba S. Tumor-associated M2 macrophages in mycosis fungoides acquire immunomodulatory function by interferon alpha and interferon gamma. J Dermatol Sci. 2016; 83: 182-9. https://doi.org/10.1016/j. jdermsci.2016.05.004.

32. Liu CJ, Kuo FC, Wang CL, Kuo CH, Wang SS, Chen CY, Huang YB, Cheng KH, Yokoyama KK, Chen CL, Lu CY, Wu DC. Suppression of IL-8-Src signalling axis by 17 betaestradiol inhibits human mesenchymal stem cells-mediated gastric cancer invasion. J Cell Mol Med. 2016; 20: 962-72. https://doi.org/10.1111/jcmm.12786.

33. Itoh Y, Joh T, Tanida S, Sasaki M, Kataoka H, Itoh K, Oshima T, Ogasawara N, Togawa S, Wada T, Kubota H, Mori Y, Ohara H, et al. IL-8 promotes cell proliferation and migration through metalloproteinase-cleavage proHB-EGF in human colon carcinoma cells. Cytokine. 2005; 29: 27582. https://doi.org/10.1016/j.cyto.2004.11.005.

34. Shao N, Chen LH, Ye RY, Lin Y, Wang SM. The depletion of interleukin-8 causes cell cycle arrest and increases the efficacy of docetaxel in breast cancer cells. Biochem Biophys Res Commun. 2013; 431: 535-41. https://doi. org/10.1016/j.bbrc.2013.01.022.

35. Huang W, Chen Z, Zhang L, Tian D, Wang D, Fan D, Wu $\mathrm{K}$, Xia L. Interleukin-8 induces expression of FOXC1 to promote transactivation of CXCR1 and CCL2 in hepatocellular carcinoma cell lines and formation of metastases in mice. Gastroenterology. 2015; 149: 1053-67 e14. https://doi.org/10.1053/j.gastro.2015.05.058.

36. Reiland J, Furcht LT, McCarthy JB. CXC-chemokines stimulate invasion and chemotaxis in prostate carcinoma cells through the CXCR2 receptor. Prostate. 1999; 41: 78-88.

37. Ning Y, Manegold PC, Hong YK, Zhang W, Pohl A, Lurje G, Winder T, Yang D, LaBonte MJ, Wilson PM, Ladner $\mathrm{RD}$, Lenz HJ. Interleukin-8 is associated with proliferation, migration, angiogenesis and chemosensitivity in vitro and in vivo in colon cancer cell line models. Int J Cancer. 2011; 128: 2038-49. https://doi.org/10.1002/ijc.25562.

38. Seaton A, Scullin P, Maxwell PJ, Wilson C, Pettigrew J, Gallagher R, O'Sullivan JM, Johnston PG, Waugh DJ. Interleukin-8 signaling promotes androgenindependent proliferation of prostate cancer cells via induction of androgen receptor expression and activation. Carcinogenesis. 2008; 29: 1148-56. https://doi.org/10.1093/ carcin/bgn109.

39. Fang W, Ye L, Shen L, Cai J, Huang F, Wei Q, Fei X, Chen X, Guan H, Wang W, Li X, Ning G. Tumor-associated macrophages promote the metastatic potential of thyroid papillary cancer by releasing CXCL8. Carcinogenesis. 2014; 35: 1780-7. https://doi.org/10.1093/carcin/bgu060.

40. Cao H, Huang Y, Wang L, Wang H, Pang X, Li K, Dang W, Tang H, Wei L, Su M, Tang C, Chen T. Leptin promotes migration and invasion of breast cancer cells by stimulating IL-8 production in M2 macrophages. Oncotarget. 2016; 7: 65441-53. https://doi.org/10.18632/oncotarget.11761. 
41. Tong H, Ke JQ, Jiang FZ, Wang XJ, Wang FY, Li YR, $\mathrm{Lu}$ W, Wan XP. Tumor-associated macrophage-derived CXCL8 could induce ERalpha suppression via HOXB13 in endometrial cancer. Cancer Lett. 2016; 376: 127-36. https:// doi.org/10.1016/j.canlet.2016.03.036.

42. Wang $\mathrm{L}$, Zhang $\mathrm{C}, \mathrm{Xu} \mathrm{J}, \mathrm{Wu} \mathrm{H}$, Peng J, Cai S, He Y. CXCL1 gene silencing inhibits HGC803 cell migration and invasion and acts as an independent prognostic factor for poor survival in gastric cancer. Mol Med Rep. 2016; 14: 4673-9. https://doi.org/10.3892/mmr.2016.5843.

43. Zhao J, Ou B, Han D, Wang P, Zong Y, Zhu C, Liu D, Zheng M, Sun J, Feng H, Lu A. Tumor-derived CXCL5 promotes human colorectal cancer metastasis through activation of the ERK/Elk-1/Snail and AKT/GSK3beta/ beta-catenin pathways. Mol Cancer. 2017; 16: 70. https:// doi.org/10.1186/s12943-017-0629-4.

44. Ogura M, Takeuchi H, Kawakubo H, Nishi T, Fukuda K, Nakamura R, Takahashi T, Wada N, Saikawa Y, Omori T, Miyasho T, Yamada S, Kitagawa Y. Clinical significance of CXCL-8/CXCR-2 network in esophageal squamous cell carcinoma. Surgery. 2013; 154: 512-20. https://doi. org/10.1016/j.surg.2013.06.013.

45. Shi J, Wei PK. Low-dose interleukin-8 induces the adhesion, migration and invasion of the gastric cancer SGC7901 cell line. Oncol Lett. 2015; 10: 2871-7. https://doi. org/10.3892/ol.2015.3641.

46. Sui $\mathrm{P}, \mathrm{Hu}$, Zhang $\mathrm{T}$, Zhang $\mathrm{X}$, Liu Q, Du J. High expression of CXCR-2 correlates with lymph node metastasis and predicts unfavorable prognosis in resected esophageal carcinoma. Med Oncol. 2014; 31: 809. https:// doi.org/10.1007/s12032-013-0809-z.

47. Nishihira T, Hashimoto Y, Katayama M, Mori S, Kuroki T. Molecular and cellular features of esophageal cancer cells. J Cancer Res Clin Oncol. 1993; 119: 441-9.

48. Stoner GD, Kaighn ME, Reddel RR, Resau JH, Bowman D, Naito Z, Matsukura N, You M, Galati AJ, Harris CC. Establishment and characterization of SV40 T-antigen immortalized human esophageal epithelial cells. Cancer Res. 1991; 51: 365-71. 